\title{
Blending Ecosystem Service and Resilience Perspectives in Planning of Natural Infrastructure: Lessons from the San Francisco Bay Area
}

\begin{abstract}
Perrine Hamel ${ }^{1,2 *}$, Maike Hamann ${ }^{3,4}$, Jan J. Kuiper ${ }^{5}$, Erik Andersson ${ }^{5,6}$, Katie K. Arkema ${ }^{1,7}$, Jess M. Silver ${ }^{1,7}$, Gretchen C. Daily ${ }^{1}$ and Anne D. Guerry ${ }^{1,7}$

${ }^{1}$ Natural Capital Project, Deptartment. of Biology and Woods Institute for the Environment, Stanford University, Stanford, CA, United States, ${ }^{2}$ Asian School of the Environment, Nanyang Technological University, Singapore, Singapore, ${ }^{3}$ Natural Capital Project, Institute on the Environment, University of Minnesota, St Paul, MN, United States, ${ }^{4}$ Centre for Sustainability Transitions, Stellenbosch University, Stellenbosch, South Africa, ${ }^{5}$ Stockholm Resilience Centre, Stockholm University, Stockholm, Sweden, ${ }^{6}$ Unit for Environmental Sciences, North-West University, Potchefstroom, South Africa, ${ }^{7}$ School of Environmental and Forest Sciences, University of Washington, Seattle, WA, United States
\end{abstract}

\section{OPEN ACCESS}

Edited by:

Dagmar Haase,

Humboldt University of Berlin,

Germany

Reviewed by:

Elzbieta Antczak,

University of Łódź, Poland

Michael w Strohbach,

Technische Universitat Braunschweig,

Germany

*Correspondence:

Perrine Hame

perrine.hamel@ntu.edu.sg

Specialty section:

This article was submitted to

Land Use Dynamics,

a section of the journal

Frontiers in Environmental Science

Received: 31 August 2020

Accepted: 14 June 2021

Published: 24 June 2021

Citation:

Hamel P, Hamann M, Kuiper JJ, Andersson E, Arkema KK, Silver JM,

Daily GC and Guerry AD (2021)

Blending Ecosystem Service and

Resilience Perspectives in Planning of Natural Infrastructure: Lessons from

the San Francisco Bay Area.

Front. Environ. Sci. 9:601136.

doi: 10.3389/fenvs.2021.601136
Globally, cities face massive environmental and societal challenges such as rapid population growth and climate change. In response, natural infrastructure is increasingly recognized for its potential to enhance resilience and improve human well-being. Here, we examine the role of the ecosystem services and resilience approaches in urban planning, which both aim to sustain the long-term benefits of natural infrastructure in cities. While the two approaches are intertwined and share deep roots in social-ecological systems framing, they confer complementary strengths in practice, which we illustrate with a case study in the San Francisco Bay Area, United States. We show that, at present, the main strength of ecosystem service practice is to provide actionable information, while urban resilience practice supports the development of holistic long-term strategies. We discuss operational limitations of both approaches and suggest that understanding and leveraging their complementary strengths could help bridge the implementation gap between research and practice in urban natural infrastructure planning.

Keywords: socio-ecological system, nature-based solution, green infrastructure, resilience practice, urban planning, action research

\section{INTRODUCTION}

Many cities already experience the effects of population growth and climate change (Global Covenant of Mayors and C40,2018). Threats from climate change-such as sea-level rise and extreme weather-often add to urban stressors like air and water pollution, housing shortages, weak transportation systems, and inequity (Revi et al., 2014), possibly compounded by extraordinary disruptions such as the COVID-19 pandemic (Phillips et al., 2020). The United Nations' international agenda recognizes these challenges; both the 11th Sustainable Development Goal (Sustainable Cities and Communities, United Nations, 2015) and the New Urban Agenda of Habitat III (United Nations, 2016) share aspirations of sustainability, resilience, safety, and inclusivity. However, the development of specific strategies and practical tactics to accomplish these high-level objectives remains elusive, highlighting the need for integrated and actionable knowledge on sustainable urban planning (Bai et al., 2016). 
TABLE 1 | Definition of key concepts used in this paper in the context of urban systems.

\begin{tabular}{|c|c|c|}
\hline Concept & Definition & Sources \\
\hline Urban ecosystem services & $\begin{array}{l}\text { Benefits that people derive from nature in cities or peri-urban areas. The } \\
\text { concept of "nature's contributions to people" is now sometimes preferred } \\
\text { over that of ecosystem services, going "further by explicitly embracing } \\
\text { concepts associated with other worldviews on human-nature relations } \\
\text { and knowledge systems." }\end{array}$ & Daily (1997); Luederitz et al. (2015); Pascual et al. (201 \\
\hline Ecosystem service approach & $\begin{array}{l}\text { A planning and decision-making approach that includes ecosystem } \\
\text { services, the diverse benefits that humans derive from nature, ensuring } \\
\text { that the complex relationships between nature and humans are more } \\
\text { clearly understood and explicitly accounted for. }\end{array}$ & Adapted from Beaumont et al. (2017) \\
\hline Ecosystem-based adaptation & $\begin{array}{l}\text { One example of an "ecosystem service approach," integrating the use of } \\
\text { biodiversity and ecosystem services to help people adapt to the adverse } \\
\text { impacts of climate change. }\end{array}$ & Colls et al. (2009) \\
\hline Urban resilience & $\begin{array}{l}\text { "The capacity of an urban system to absorb disturbance, reorganize, } \\
\text { maintain essentially the same functions and feedbacks over time and } \\
\text { continue to develop along a particular trajectory." Resilience "explores the } \\
\text { persistence, perseverance and potential alternative configurations of a } \\
\text { complex system subject to (uncertain) changing conditions, and links to } \\
\text { the adaptive and transformative capacities of subsystems interacting } \\
\text { across scales and over time." }\end{array}$ & Elmqvist et al. (2019); Folke et al. (2016) \\
\hline Resilience practice & $\begin{array}{l}\text { Applications of resilience thinking in real-world settings, including but not } \\
\text { limited to planning, or in the form of resilience assessments. }\end{array}$ & $\begin{array}{l}\text { Sellberg et al. (2018), adapted from Walker and Salt } \\
\text { (2012) }\end{array}$ \\
\hline $\begin{array}{l}\text { Natural infrastructure or blue and } \\
\text { green infrastructure }\end{array}$ & $\begin{array}{l}\text { "The interconnected network of natural and semi-natural elements capable } \\
\text { of providing multiple functions and ecosystem services," which is used } \\
\text { broadly to refer to trees, green roofs, vegetated stormwater management } \\
\text { systems, rivers and vegetated river banks, wetlands, and urban parks of } \\
\text { many sizes and forms. }\end{array}$ & $\begin{array}{l}\text { Benedict and McMahon (2006); Bartesaghi Koc et al. } \\
\text { (2017); Silva and Wheeler (2017) }\end{array}$ \\
\hline Nature-based solutions & $\begin{array}{l}\text { "Actions to protect, sustainably manage, and restore natural or modified } \\
\text { ecosystems, that address societal challenges effectively and adaptively, } \\
\text { simultaneously providing human well-being and biodiversity benefits." } \\
\text { Natural infrastructure in cities represents the structural elements of these } \\
\text { solutions, such as indicated in the row above. }\end{array}$ & Cohen-Shacham et al. (2016) \\
\hline
\end{tabular}

Urban green and blue infrastructure, hereafter termed "natural infrastructure" (Table 1), holds great promise for addressing sustainability and livability challenges in cities (Frantzeskaki, 2019). The idea of using natural infrastructure to address urban challenges is gaining widespread traction in urban planning and governance. High-level political organizations such as multilateral banks and the European Commission (World Bank, 2017; Lafortezza et al., 2018; WWAP/UN-Water, 2018) are promoting it heavily, as are action-oriented networks such as the Local Governments for Sustainability network (ICLEI), the C40 cities climate leadership group, the Global Resilient Cities Network (formerly 100 Resilient Cities), and the World Bank's Global Platform for Sustainable Cities.

The promise of natural infrastructure is to provide a suite of benefits to society, including improving well-being and building resilience to internal and external pressures (McPhearson et al., 2015; Andersson et al., 2017). City parks help reduce temperatures and associated public health risks during heat waves (Keeler et al., 2019), while vegetation, dunes, and other shoreline ecosystems and open space can reduce coastal flood risk for people and property (e.g. Arkema et al., 2013; Langridge et al., 2014; Hochard et al., 2019). Urban greenery also provides mental health benefits and can help build social cohesion (Bratman et al.,
2019; Keeler et al., 2019) - two essential qualities that aid in recovery from social shocks such as the major disruptions experienced during the COVID-19 pandemic. Importantly, to enhance long-term sustainability and livability, natural infrastructure needs to be robust and reliable over time (McPhearson et al., 2015; Andersson et al., 2017). This entails building resilience around the flows of benefits from natural infrastructure, in the face of a variety of potential changes, such as intensifying climate change or population growth.

Despite their great potential, natural infrastructure solutions are not currently being used on the scale needed to address the urgency of global urban sustainability challenges (Wamsler et al., 2016; Depietri and McPhearson, 2017; Lafortezza et al., 2018; WWAP/UN-Water, 2018). Two types of approaches, both of which have gained significant traction in natural infrastructure research and practice, aim to reduce this implementation gap: one focuses on "ecosystem services," the other on "resilience thinking." Both approaches inform a broad range of practices known as nature-based solutions, ecosystem-based adaptation, or blue and green (or natural) infrastructure planning (see definitions in Table 1). Yet, despite the large body of research on resilience thinking, resilience practice remains an emerging concept in urban sustainability (Quinlan et al., 2015; Sellberg et al., 2015; Elmqvist et al., 2019). Similarly, to date, the concept of 
ecosystem services has been applied only sparsely in urban planning (Hansen et al., 2015; Kremer et al., 2016; Cortinovis and Geneletti, 2018; Saarikoski et al., 2018; Thompson et al., 2019) and is only just beginning to be applied systematically to inform decision-making in cities.

The motivation for this paper is to highlight complementarities between the two approaches, in theory and practice, and to scrutinize their potential to inform urban planning. Historically, resilience thinking and ecosystem service approaches grew from the same roots of social-ecological systems thinking (Folke et al., 2016; Reyers et al., 2018). Both schools of thought emerged from the idea that social and ecological systems are closely linked by multiple feedback mechanisms, and that understanding and managing ecosystems cannot be done by considering humans or nature in isolation. In practice, both approaches have a normative orientation toward enhancing urban sustainability (RomeroLankao et al., 2016; Elmqvist et al., 2019). Despite the common roots and conceptual interweaving, research and practice in urban ecosystem services and urban resilience have often followed separate paths and now represent only partially overlapping bodies of knowledge (Bush and Doyon, 2019). In particular, they offer different analytical frameworks to guide efforts toward sustainable urban planning and governance, resulting in different communities of practice (e.g., Ecosystem Services Partnership (https://www.espartnership.org/) and the Resilience Alliance (https://www. resalliance.org/()). Urban ecosystem service approaches focus on the multitude of benefits that people gain from natural infrastructure and propose designing urban landscapes that enhance these benefits for urban residents (Hansen et al., 2015; Cortinovis and Geneletti, 2018; Cortinovis and Geneletti, 2019). The practice of urban resilience is broader, embracing the idea that cities are complex social-ecological systems subject to change and unpredictable events. Thus, urban planning and governance strategies based upon resilience thinking focus on adaptation and transformation, with the understanding that the benefits people derive from ecosystems are continuously evolving (Wilkinson, 2011; Meerow et al., 2016).

Here, we examine the primary insights for natural infrastructure planning gained from ecosystem service approaches and resilience thinking. Our main contribution is to synthesize the promises of each approach and illustrate their strengths and limitations in a case study. To do so, we first summarize their potential by reviewing recent literature from both communities of practice. We then use our experience from a recent engagement in the San Francisco Bay Area, United States, to explore how these promises materialize in practice. We illustrate that both approaches can meaningfully contribute to urban infrastructure planning and provide complementary ways to operationalize a systems approach to urban sustainability, covering different spatio-temporal dimensions. The niche of urban ecosystem service practice is to provide actionable knowledge to support urban planning decisions, while that of resilience practice is to support the development of holistic and adaptive long-term strategies. From this observation, we propose recommendations for bridging the implementation gap in the fields of natural infrastructure planning for cities.

\section{PROMISE OF ECOSYSTEM SERVICES AND RESILIENCE APPROACHES FOR NATURAL INFRASTRUCTURE PLANNING}

\section{Ecosystem Service Approach: Quantitative Mapping of Supply and Benefits}

Historically, the conceptualization of ecosystem services distinguishes the ecological sphere, where ecological functions occur (e.g., evapotranspiration), and the social sphere, where benefits are received (e.g., urban dwellers experiencing lower urban temperature) and valued (e.g., urban dwellers enjoying improved health or lower air conditioning expenses). This conceptualization, evident in what is called the "ecosystem services cascade," requires a clear identification of ecosystems and beneficiaries, which are often represented spatially (Braat and de Groot, 2012; Tallis et al., 2012; Burkhard et al., 2014; Ochoa and Urbina-Cardona, 2017). More recently, the concept of ecosystem services has evolved to blur the distinction between the social and ecological, and acknowledge the pivotal role of human action in "co-producing" benefits from ecosystems (Reyers et al., 2013; Palomo et al., 2016). Linear "stock-and-flow" models and the idea of an "ecosystem service cascade" are increasingly expanded to a more systems-based understanding of cross-scale feedbacks between ecosystem service co-production, contribution to wellbeing, and management or governance of ecosystems (Díaz et al., 2015; Masterson et al., 2019). This understanding recognizes multiple ways of knowing and the multiple value systems, which were often absent in earlier ecosystem services work (Pascual et al., 2017; Díaz et al., 2018).

Given the history of ecosystem services and their early application in landscape and conservation planning, the scientific literature highlights two characteristics of ecosystem service approaches that make them particularly salient to natural infrastructure planning in cities: their compatibility with quantitative, spatially-explicit planning processes, and the possibility to assess multiple benefits and tradeoffs of alternative planning scenarios. Because ecosystem services measure benefits to society, they can be readily incorporated into socio-economic models to inform urban planning (Baró et al., 2016; Bush and Doyon, 2019; Keeler et al., 2019; Geneletti et al., 2020). By making visible the connections between ecological functions and the health and wellbeing of people, and the values associated with them, ecosystem services approaches can directly inform policies and plans (e.g., climate action plans, Munang et al., 2013; Geneletti and Zardo, 2016). They can either be used to enhance benefits for the entire population of a city or to increase benefits for specific subgroups (e.g., through regulatory or incentive-based tools; Cortinovis and Geneletti, 2018). Relatedly, ecosystem service approaches are inherently spatial; they require understanding the flow of benefits from specific ecosystems to specific urban 
populations (BenDor et al., 2017; Cortinovis and Geneletti, 2019). This characteristic speaks well to planners and landscape architects that have a spatial understanding of infrastructure and the services it provides. Maps and other spatial representations help to make knowledge of ecosystem services actionable, greatly facilitating engagement with different groups of stakeholders (Ruckelshaus et al., 2015), an important feature in recent urban planning practice (Albrechts, 2004; Wilkinson, 2011; BenDor et al., 2017).

In addition, ecosystem service approaches recognize multiple benefits and tradeoffs between services, potential disservices, and the presence of substitutes in urban environments (Bennett et al., 2009; Keeler et al., 2019). For example, urban greenspaces can help store and infiltrate water (providing water supply and flood mitigation services) and typically constitute areas for exercise and social activities (conferring recreation and physical and mental health services). However, greenspaces also lose water through evapotranspiration (a disservice), and their water supply service could be provided by other solutions (e.g., rainwater harvesting tanks). This means that information about ecosystem services can be used to achieve multiple goals (from carbon sequestration to recreation to water management) and connect different city departments (e.g., parks and recreation with stormwater management). The consideration of multiple benefits and tradeoffs makes it essential to bring stakeholders and experts with diverse perspectives to the decision-making table, such that the iterative process leading to information co-production has become a hallmark of ecosystem services approaches (Rosenthal et al., 2015; Beaumont et al., 2017). In this context, the use of scenarios enables the evaluation of goals and tradeoffs across planning alternatives, especially when combined with ecosystem service models like InVEST to quantify benefits and produce spatial maps for collaborative assessment (Rosenthal et al., 2015).

\section{Resilience Approach: Building Capacity to Deal With System Dynamics and Uncertainty}

Resilience thinking, with its origin in complex systems theory, provides a lens to analyze the ability of complex systems to deal with change, uncertainty, and surprise (Folke et al., 2016). In this context, cities are seen as complex adaptive systems that are continuously evolving along multiple possible development pathways (Elmqvist et al., 2019). Since urban ecosystems tend to be highly artificial and heavily managed (Hobbs et al., 2006), a reliable delivery of ecosystem services over time requires managing infrastructure-in particular natural infrastructure-in a way that adapts to changing circumstances such as environmental factors, financial sources, and political and societal trends (McPhearson et al., 2015). One of the salient features of resilience practice lies in equipping planners with a suite of generic principles, or strategies, for enhancing urban resilience in the face of change and uncertainty (Biggs et al., 2012; Wardekker et al., 2020). Resilience scholars highlight a number of key strategies for building resilience around the benefits of natural infrastructure, including: promoting polycentric, participatory, and adaptive governance processes, fostering complex systems thinking, encouraging continuous learning and experimentation, and nurturing stewardship (Biggs et al., 2012; Andersson et al., 2015; Quinlan et al., 2015; Crowe et al., 2016; Andersson et al., 2017).

Several frameworks have been developed to analyze complex systems, such as frameworks that focus on the relationships between social, ecological, and technological sub-systems (McPhearson et al., 2016), or those that focus on analyzing structure and processes (Quinlan et al., 2015; Pauleit et al., 2017). In the latter, urban systems' structure comprises built (e.g. transportation systems, water supply, electricity networks) and natural (e.g. parks, coastal vegetation) infrastructure that supply services to people. Institutions like local authorities, research centers, or civil society organizations can be considered part of an urban system's structure (or "soft" infrastructure). They support urban processes by determining the possible links between actors. Urban systems' processes can be viewed as the interactions between actors or agents (including animals and plants) that shape and maintain patterns over time. In cities, humans are key actors in most of the formative processes through their ability to self-organize, govern, collaborate, anticipate, learn, inspire, adapt, etc. For a given system's structure, interactions between agents may vary considerably depending on individual agencies, power relations, and historical legacies. For example, urban park use depends not only on the physical structure of a park (e.g., presence and condition of amenities, types of green infrastructure) but also its history and social values that have been shaped by dynamic processes of usage or exclusion (Byrne, 2012; Wang et al., 2015).

This conceptualization of cities as complex systems that are characterized by structures and processes highlights the importance of governance for promoting urban resilience. In particular, forms of governance which recognize the importance of social network dynamics and can deal with complex, crossscale interactions, help build resilience of natural infrastructure (Andersson et al., 2017; Borgström, 2019; Elmqvist et al., 2019). Such forms of governance tend to be polycentric, recognizing the plurality of social networks (Biggs et al., 2012). They involve adaptive management and participation from a broad range of stakeholders to expand knowledge of the system and increase legitimacy (Biggs et al., 2012; Crowe et al., 2016; Bush and Doyon, 2019). They also embrace systems thinking by explicitly recognizing the links, or feedback loops, between natural infrastructure management and ecosystem services (Wilkinson, 2011; Andersson et al., 2017). Finally, they acknowledge the importance of addressing stewardship capacity in natural infrastructure planning. Although stewardship can be professionalized and institutionalized (Fisher et al., 2012; Johnson et al., 2019), an important aspect of resiliencebuilding happens at the level of individuals and communities. Stewardship capacity at the individual and organizational level can be promoted in green space governance (Andersson et al., 2017) by engaging different communities and fostering a shared understanding of, and care for, the urban system. A process to consider and apply different principles of resilience 
to a social-ecological system can be designed, as in the case of resilience assessments (Enfors-Kautsky et al., 2018).

\section{Ecosystem Services and Resilience as Boundary Objects}

Given their increasing appeal to business leaders, elected officials, scientists, and the public alike, a final and important promise of both ecosystem services and resilience concepts is their role as boundary objects for urban planning and sustainability (Brand and Jax., 2007; Abson et al., 2014; Luederitz et al., 2015; Meerow et al., 2016). Boundary objects are objects or ideas that enable different communities to develop a common language, collaborate, and solve problems in innovative and potentially more effective ways. This is true even if precise understanding and use of the boundary objects may differ among communities, and full consensus is not required (Leigh Star, 2010; Steger et al., 2018). Both ecosystem services and resilience concepts play this role by emphasizing collaboration across disciplines, including engineering, natural, and social sciences, and between science, technology, and society. Their adoption by organizations such as the World Bank and the Rockefeller Foundation also contributed to their popularization, turning the concepts into attractors of attention and funding (Rockefeller Foundation and ARUP, 2014; Ozment et al., 2019; World Bank Group, 2021).

However, the malleability of boundary objects means that they can be stretched or evolve rapidly, in turn resulting in conceptual ambiguity and dilution of their descriptive power (Brand and Jax., 2007; Thorén, 2014; Schleyer et al., 2017). Consequently, there is almost a continuous need for practical operationalization of ecosystem service and resilience approaches in different urban planning and management contexts (Wilkinson, 2011; Cortinovis and Geneletti, 2018; Keating and Hanger-Kopp, 2020). The operationalization and standardization of ecosystem services in some countries led some scholars to argue that provisioning and regulating ecosystem services are transitioning out of the "boundary object" status as they become ever more standardized (Steger et al., 2018).

\section{PRACTICE OF URBAN ECOSYSTEM SERVICES AND RESILIENCE}

Having summarized the promises of ecosystem services and resilience approaches, we now discuss their strengths and limitations in practice, drawing on our experience in the San Francisco Bay Area, United States. The case study provides examples of action-oriented social-ecological research focusing on natural infrastructure planning. By highlighting both strengths and future opportunities, we provide insights into the complementarity of the ecosystem services and resiliencecentered approaches. Our assessment is mainly qualitative and builds on observations, informal conversations, and analyses of documents and products from our engagement in the San Francisco Bay Area. We acknowledge that some of the findings are contextual since there is no single ecosystem service or resilience approach in practice. In the discussion that follows, we thus situate our findings in the broader literature to generalize the arguments.

\section{Case Study \\ Background}

In 2017, some of our author team began work aimed at assessing ecosystem services and their potential to increase the resilience of California's San Francisco Bay Area to sea-level rise. The San Francisco Bay Area is home to about 7.4 million people living in nine counties (Adapting to Rising Tides, 2020). A significant share of the population and critical infrastructure are located along the shorelines and threatened by sea-level rise, which adds to important pressures brought by a growing population and urban development (Adapting to Rising Tides, 2020). After a scoping phase aimed at understanding the institutional landscape and legacies from past resilience-building projects, we identified key stakeholders and partnered with a state planning and regulatory agency (the Bay Area Conservation and Development Commission, BCDC), a regional science institute (the San Francisco Estuary Institute, SFEI), local government (San Mateo County's Office of Sustainability), two nongovernmental organizations (The Nature Conservancy, Point Blue Conservation Science), and academic collaborators. Together, we aimed to explore the multiple benefits provided by natural habitats to people, including how those benefits will be impacted by sea-level rise and how they might be used in adaptation strategies. Some of this work was embedded within BCDC's broader effort to explore the vulnerability of four different kinds of "assets" to sea-level rise: transportation infrastructure, disadvantaged communities, areas designated as priorities for development, and areas designated for conservation.

\section{Approach to Support Natural Infrastructure Planning}

To support the regional vulnerability assessment of BCDC, we modeled habitat for biodiversity together with four ecosystem services-coastal risk reduction, stormwater runoff retention, groundwater recharge, and recreation-provided by natural infrastructure in the Bay Area, producing regional maps for each service that can help identify patterns of ecosystem service provision (see examples in Figure 1) now and under future sea-level rise scenarios. At a finer scale, in San Mateo County (one of the nine counties in the Bay Area), we compared how biodiversity and the provision of ecosystem services would likely be affected by different sea-level rise adaptation scenarios. Details of the geospatial models are beyond the scope of this manuscript, which focuses on the co-production approach, and available from the authors. Together with stakeholders, we cocreated three scenarios of adaptation to sea-level rise: one in which built infrastructure was the default solution to protect people and property along the County's shore (designed only for comparison); the second in which current and planned wetland restoration projects were considered as nature-based solutions for flood protection; and the third in which we extended these current and planned projects for additional flood protection through additional habitat conservation, restoration, and creation wherever deemed feasible (from both ecological and social perspectives). We then compared the ecosystem services 


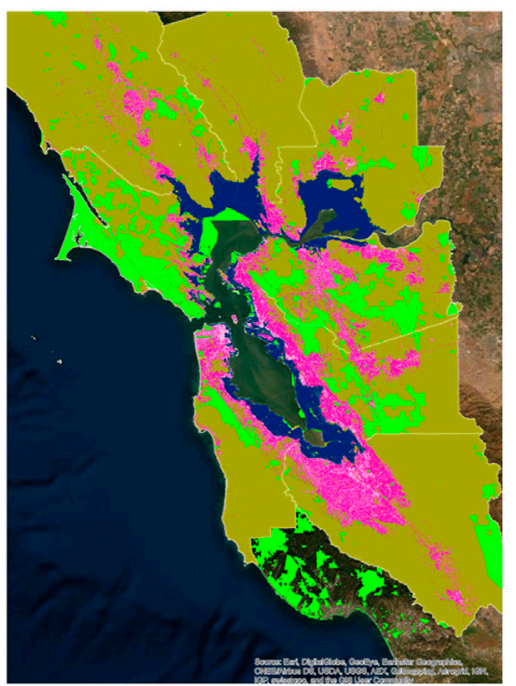

Land use

Natural areas without protection

Natural areas with protection

Developed areas

96" Sea-level rise

Nine Bay Area counties

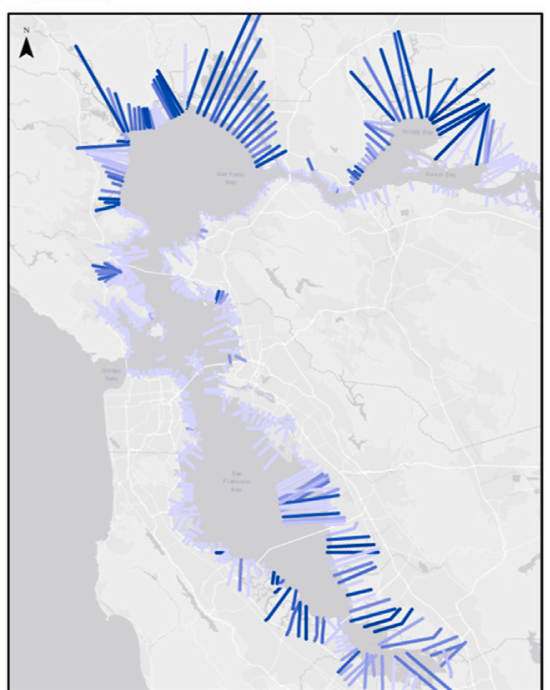

Coastal Protection

Reduction in wave

height at shore $(\mathrm{ft})$

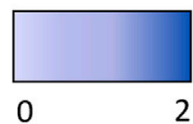

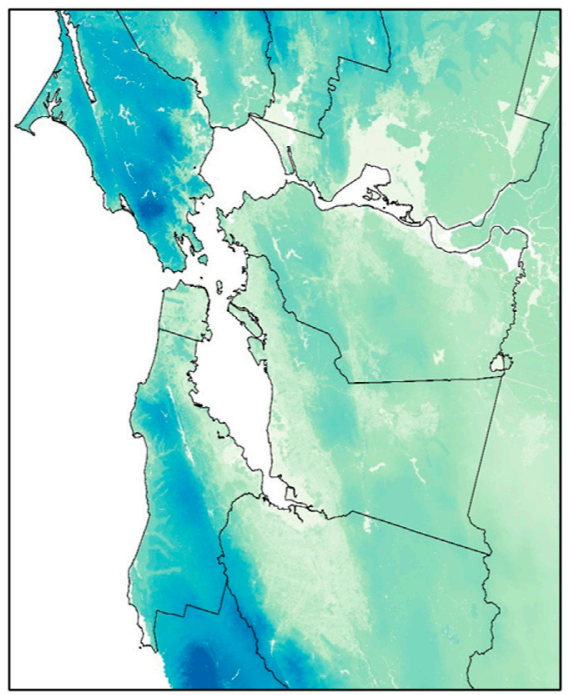

\section{Stormwater Retention}

Retention volume $\left(\mathrm{m}^{3}\right)$
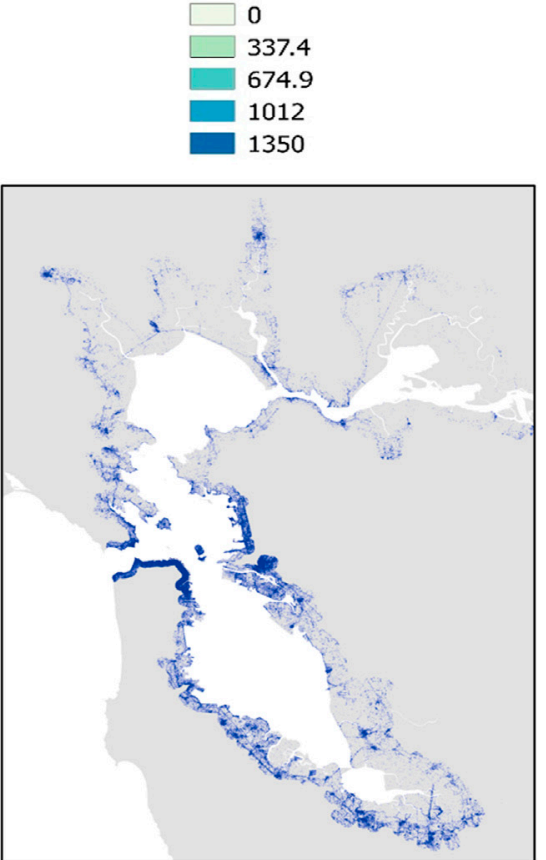

Coastal Recreation

Photo User Days

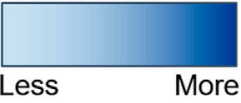

FIGURE 1 | Natural habitat and three ecosystem services (Stormwater Retention, Coastal Proetection, Coastal Recreation) quantified and mapped in the San Francisco Bay Area. The maps support discussions on current and expected changes in ecosystem services provision.

provided by each scenario based on metrics associated with each service (e.g., metrics shown in Figure 1) to help inform adaptation actions.
During the engagement process, we organized or participated in more than 10 workshops with the project partners and stakeholders to develop and refine the ecosystem service 
analyses. One of these workshops specifically aimed to introduce the concepts of resilience as formalized in the social-ecological systems literature (Table 1). It involved representatives of BCDC, San Mateo county, SFEI, California State Coastal conservancy, Point Blue Conservation Science, Port of San Francisco, in addition to academic partners. In that workshop, we conducted various activities to compare individuals' understanding of the systems' dynamics, examining how the local value of current ecosystems had evolved and why, and based on that information facilitated thought experiments of what a desirable future may look like ("positive futures" exercise). The workshop was considered a success by participants, in part because it invited them to think differently about possible futures and how to achieve them.

The long-term outcomes of this work have yet to be seen, but our engagement confirmed that stakeholders and decisionmakers in the region highly value information about the benefits provided by natural infrastructure, how they are at risk from sea-level rise, and where and when nature-based solutions can help the region adapt as the climate changes. The maps produced throughout the project are an important step forward to provide such information. All the information produced is available to stakeholders and important layers are made public on a webtool (https://www.bayareagreenprint.org/) to support future regional planning (Adapting to Rising Tides, 2020).

\section{Assessment Through an Ecosystem Services Lens \\ Strengths of the Approach}

Compatibility with quantitative planning processes. One important output of the San Francisco Bay Area case study is the production of multiple maps and summary information of natural infrastructure and ecosystem services to understand service provision today and in possible futures. This work focused primarily on the system's infrastructure-both built and natural. The focus on structural elements and their services facilitated interactions with the large number of organizations involved in the project, which is an important part of the planning process. For example, co-producing maps was an opportunity to harmonize many different sources of information coming from different partners. The knowledge of existing and planned restoration projects, local ecology and sealevel rise, and visions and values held in coastal communities could readily be used to inform the adaptation scenarios, e.g. through the selection of the subset of ecosystem services evaluated in the study. One benefit of using spatially-explicit scenarios and an ecosystem services framework is that they together lend themselves to exploring who benefits from particular services. Maps of ecosystem services combined with, e.g., demographic maps representing the beneficiaries (Burkhard et al., 2014; Ochoa and Urbina-Cardona, 2017) can show where particular services are delivered and to whom. Such analyses can help planners address inequality in access to nature's benefits.

Comparing multiple benefits and tradeoffs of natural infrastructure across scenarios. Although the project partners generally shared a common understanding of the potential benefits of natural infrastructure from the beginning of the project, they needed to be able to examine multiple benefits of natural infrastructure simultaneously, and explore when and where natural infrastructure was feasible ecologically, socially, and under different sea-level rise scenarios (regional scale). At the County scale, the summaries of ecosystem services provided by alternative adaptation scenarios highlighted some of the benefits and tradeoffs between built and natural infrastructure, taking into consideration what is feasible at different locations throughout the Bay. The process of co-developing scenarios and ecosystem services information was effective in creating new shared knowledge not only on the coastal protection services provided by natural infrastructure, but also on other benefits such as stormwater management, carbon storage and sequestration, habitat provision, and recreational opportunities (e.g., summarized in a project report, Adapting to Rising Tides, 2020).

\section{Opportunities for Expanding the Project Scope}

Incorporating more diverse values and value systems. The project partners selected the suite of ecosystem services to assess in the case study based on consultations with multiple stakeholders in the Bay Area and based on models and data that were readily available to the team. Although the importance of stormwater management, groundwater recharge, carbon sequestration, coastal risk reduction, and provision of habitat for wildlife is not questioned, this selection is biased toward regulatory services. Of the services modeled, only recreation falls into the "cultural" ecosystem services category, and its assessment was not sensitive to different community groups (it only considered the number of social media users as a proxy for visitation).

Future work could further assess cultural ecosystem services in the study area as a way to improve outreach and promote a better understanding of the links between ecosystems and their societal benefits (Andersson et al., 2015). Assessing cultural services such as sense of place or esthetic quality, for example by examining how marshes are perceived and valued by different community groups, would help meet two goals: First, it could increase chances that stakeholders outside the conservation community engage in conversations about nature-based solutions, by making the links between people and natural infrastructure more tangible. Second, it could provide useful insights into stewardship and the support that ecosystems and their benefits might receive in the future (see next section). The need for ecosystem service approaches to be more inclusive of diverse values and value systems (e.g., recognizing non-instrumental values such as relational values) is reflected in the recent call by the Intergovernmental Panel on Biodiversity and Ecosystem Services (IPBES) to consider nature's contributions to people beyond ecosystem services (Díaz et al., 2018).

\section{Assessment Through a Resilience Lens Strengths of the Approach}

Polycentric governance. In the San Francisco Bay Area, recent efforts have focused on building capacity (on governance and adaptation to sea-level rise), understanding vulnerabilities, and 
identifying diverse ways that local communities value their environment (Nutters, 2012; Lavine, 2013; Adapting to Rising Tides, 2016). One outcome of these efforts is the establishment of a network of partners working with communities and government agencies with a common goal to increase resilience to sea-level rise. Our work leveraged these efforts by establishing collaborations with multiple stakeholders working at different scales-regional and county-level-and co-developing information on natural infrastructure that was relevant for different levels of governance. For example, specific scenarios of natural infrastructure implementations were developed for San Mateo County, whereas the regional level analyses focused on providing spatial information on where across the entire Bay ecosystems provided the highest levels of services now and under climate change.

Participatory process and social learning. Another important principle of building resilience highlighted in Promise of Ecosystem Services and Resilience Approaches for Natural Infrastructure Planning section relates to broadening participation and learning. In the San Francisco Bay Area case study, in addition to co-developing the project with multiple stakeholders, we made the information on ecosystem services accessible through the Bay Area Greenprint webtool, through summary leaflets for stakeholders produced by San Mateo County, and through a project report (Adapting to Rising Tides, 2020). Although by no means sufficient, providing access to information helps empower local stakeholders to participate in future infrastructure planning projects in the region. One of the challenges to participation is the size of the Bay Area and number of institutional and civil society actors, which make the system incredibly complex. Internet-based tools providing information such as the Bay Area Greenprint are rapidly expanding the possibilities for mass participation in natural infrastructure governance (Steen Møller and Stahl Olafsson, 2018; Samuelsson et al., 2019).

\section{Opportunities for Expanding the Project Scope}

Adaptive management of ecosystems and understanding socialecological feedback loops. Although we partnered directly with local institutions and worked with stakeholders, the work in San Francisco could be expanded to explore the role of the "soft" infrastructure of institutions and governance more explicitly. Our collaboration with multiple organizations implied that we incorporated some governance questions implicitly, but we did not focus our ecosystem services assessment on socio-ecological systems' dynamics or management practices. A resilience lens could strengthen the assessment by scrutinizing the important links between management of ecosystems and the services they provide, as well as how management may need to be adapted over time to respond to climate change and other stressors of the urban systems. At the simplest level, future work could examine the management practices used in different habitats (e.g., species used in coastal restoration activities) and assess the effect on ecosystem service provision, as well as the links back to human well-being. More thorough analyses could look at land tenure, an important factor influencing the management of ecosystems. Ownership of open space in the Bay Area is split between public and private actors, which means that coordinated actions, or collaborative governance, are needed to sustain ecosystem services in the long term (Ernstson et al., 2010; Andersson et al., 2017).

Changing governance and stewardship capacity. Many studies have illustrated the key role played by municipal and regional agencies and governments (Colding and Barthel, 2013; Buijs et al., 2016; Borgström, 2019), both for their capacity to act as brokers and for their ability to provide support and continuity for initiatives that otherwise might be short-lived. Thus, an important addition to ecosystem services assessments could be to examine how these collaborative forms of governance (combining local stewardship groups and organizations with a long-term mandate and resources) are currently promoted or may be strengthened over time (Andersson et al., 2007). In particular, analyses could focus explicitly on the potential of various actors to remain or become stewards, since stewardship supports long-term protection of the ecosystems and therefore of the services they provide (Andersson et al., 2007).

In practice, straightforward ways to incorporate these considerations in the analyses would be to add new scenarios and to improve their interpretation, a suggestion that emerged late in the project, during the resilience workshop held by the team. For example, the natural infrastructure scenario at the county scale could explicitly identify the governance changes needed to lead to particular, hypothetical scenarios of natural infrastructure implementation. Additional scenarios could also represent the effect of different selections of species and management options in restoration projects, highlighting the importance of management on ecological functions.

\section{DISCUSSION: IMPLICATIONS FOR RESEARCH AND PRACTICE IN URBAN NATURAL INFRASTRUCTURE PLANNING}

\section{Building on Strengths of Ecosystem Services and Resilience Approaches}

In Figure 2, we summarized the main applications of ecosystem services and resilience concepts used in the case study. We classify these approaches by primary focus, i.e. ecosystem services or resilience building, recognizing the overlaps between the two. The strengths of ecosystem services approaches stem from the focus on structural elements: they can easily be incorporated into quantitative planning processes; they facilitate the assessment of multiple benefits and tradeoffs across alternative management options; and their consideration helped collaboration among diverse groups. In that sense, our analyses confirm the results of other studies that recognize the potential of the ecosystem services concept-highlighting the salience of ecological information in planning processes (Hansen et al., 2015; Baró et al., 2016; Kaczorowska et al., 2016; BenDor et al., 2017; Brunet et al., 2018; Cortinovis and Geneletti, 2019). As stated in Promise of Ecosystem Services and Resilience Approaches for Natural Infrastructure Planning section, we emphasize that the iterative and collaborative process of knowledge co-production is central to ecosystem services approaches (Díaz et al., 2015; Rosenthal et al., 2015; Díaz et al., 2018). When it comes to assessing 


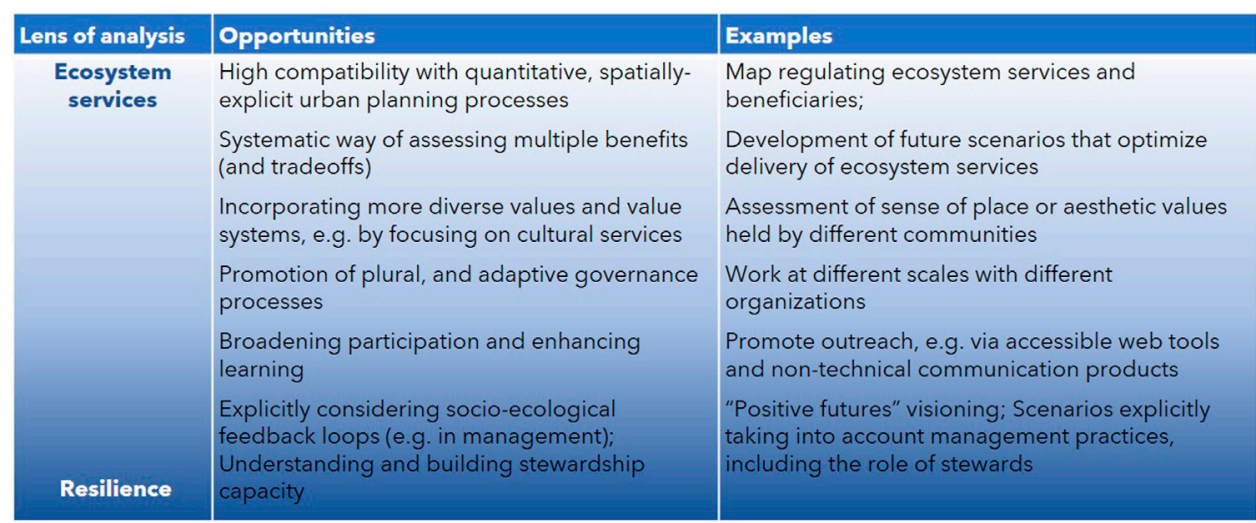

FIGURE 2 | Opportunities (realized and potential) to support natural infrastructure planning, identified by using ecosystem services and resilience lenses. The distinction between the lenses does not mean that these opportunities are mutually exclusive. On the contrary, using one lens or the other allows leveraging of opportunities offered by both fields.

multifunctionality and tradeoffs between ecosystem services in the context of urban planning, scholars call for better consideration of the different dimensions across which tradeoffs could occur (e.g., spatial, temporal, diversity) (Bush and Doyon, 2019), and the different roles and asymmetries in power among participating stakeholders (Turkelboom et al., 2018), which resilience practice explicitly acknowledges.

The main strengths of resilience practice were to promote a holistic and more dynamic view of the system by promoting adaptive and plural governance, considering feedback loops (especially through management), broadening participation, and building stewardship capacity. Here also, our analyses support existing literature highlighting the potential of the resilience concept for urban planning-pointing to the development of long-term, holistic thinking to inform urban planning processes (Andersson et al, 2015; McPhearson et al., 2015; Bush and Doyon, 2019; Elmqvist et al., 2019; Meerow and Newell, 2019). Through the action research project presented here, our analyses provide concrete examples of how the potential of ecosystem services and resilience thinking can be realized in practice. Our post-hoc analyses suggest that some of the potential strengths were not leveraged, as is inevitably the case in real-life projects. Yet the summary of strengths and opportunities in Figure 2 provides a checklist of opportunities for future research efforts.

Figure 2 further illustrates that while ecosystem service approaches often focus on structure, resilience approaches better integrate a focus on both structure and processes. However, these largely overlap; a given strategy will affect several aspects of the system, related to structure and processes. A simple example is the production of ecosystem service maps in the San Francisco Bay Area case study (Figure 1). The primary purpose was to understand the current value of services provided by natural infrastructure, to adapt to potential future changes in these services. However, an important outcome of this process was the shared understanding of ecosystems of the Bay Area for actors that traditionally had a narrower perspective (e.g., conservation agencies, transportation agencies), and thereby facilitating interactions between them. The dual outcomes of some engagement strategies, intentional or not, means that the distinction between strategies relating to structure (often a focus of ecosystem services analyses) and those relating to processes (often favored by resilience thinking) is blurred. Structure enables processes and changes the system's dynamics, which in turn influence the structure (e.g., changing institutions or physical infrastructure).

We suggest that the potential of the two approaches to address structure and process in mutually beneficial ways may be of particular use in the context of environmental justice, and particularly justice around nature-based solutions. Redressing the social-ecological inequalities of urban systems requires not just a fine-grained understanding of the spatial structures that maintain and perpetuate an unjust system, but also necessitates planning and implementation processes that are, among other things, participatory and inclusive of diverse stakeholders and value articulations (Kabisch et al., 2016; Shi et al., 2016; Bush and Doyon, 2019; Cousins, 2021). This suggests that the two communities of practice should further build on the strengths of each other to inform natural infrastructure implementation with a balanced focus on structure and dynamics.

\section{Addressing Operational Limitations of Ecosystem Services and Resilience Approaches}

The opportunities identified in our case study mirror an important limitation of both ecosystem services and resilience approaches, namely their operationalization. We found that our work in the San Francisco Bay Area could be augmented by incorporating more resilience thinking in the form of considering management impacts on ecosystem services, and more generally considering socioecological feedback loops in the urban system. This points to the difficulty of operationalizing resilience thinking, which is well documented (Wagenaar and Wilkinson, 2015; Crowe et al., 2016; Hernantes et al., 2019; Meerow and Newell, 2019). Current practice is still hindered by the different meanings that different communities-engineering, ecological, or socialecological-associate with the concept (Quinlan et al., 2015; Meerow et al., 2016). For example, engineering firms propose 
analytical frameworks to design and implement "resilience-building projects," combining built and natural infrastructure (e.g., consulting firms' design guidelines). Although they incorporate social, ecological, and technical dimensions, in practice such approaches often focus on structural solutions, ignoring important aspects of the social-ecological system's resilience. Tools embracing a more holistic view of resilience often remain conceptual or lack specificity. For example, the City's Resilience Index promoted by the C40 is a highlevel analytical framework and a knowledge platform (Spaans and Waterhout, 2017), but provides little practical guidance on how to manage or measure resilience in practice.

Understanding and ultimately transforming urban systems' dynamics through natural infrastructure requires long-term engagement and trust, which means investments in time and capacity. A downside of the resilience thinking principles is that planners and managers often do not have the resources to apply resilience approaches and grapple with complexity (Quinlan et al., 2015; Wagenaar and Wilkinson, 2015; Meerow et al., 2016; Hernantes et al., 2019). Whether this is due to a low amount of resources or a misallocation of these resources (assuming that understanding system's dynamics or applying adaptive management will be easy), it results in a missed opportunity to leverage insights of resilience thinking in practice. Recognizing these long timeframes, Hernantes et al. (2019) propose a "maturity model" to help operationalize resilience thinking. According to their framework, cities pass through five sequential maturity stages, each associated with a level of collaboration with various stakeholders (local government, public and private companies, NGOs, academia, etc.) This model can be used as a guide to understand the degree to which resilience thinking is embedded in the system and allocate resources accordingly. Given how early cities are generally in this maturation process, there remains a crucial need for operational guidance. Recent efforts recognize this need by developing protocols and communication products to help practitioners navigate the multiple dimensions of resilience practice (e.g.; Adapting to Rising Tides, 2016; DEAL, 2020; Enfors-Kautsky et al., 2018; van de Ven et al., 2016).

The operationalization challenge also affects ecosystem services approaches, although to a lesser extent. Recent research suggests that the concept of ecosystem services increasingly influences urban planning practice (BenDor et al., 2017; Brunet et al., 2018; Cortinovis and Geneletti, 2018), although still facing difficulties to identify and communicate the added value of ecological information (Hansen et al., 2015; Kaczorowska et al., 2016). Brunet et al. (2018) suggest that actionable knowledge on ecosystem services could be produced by providing quantitative measures of ecosystem services, visualizing results, and using storytelling and gaming to improve communication. Our study illustrates these findings by identifying the main strengths of the San Francisco Bay Area work (Figure 2) as the co-production of quantitative maps of ecosystem services and improving outreach and participation. The ecosystem services community of practice recognizes the importance of rapidly accessible information as suggested by a growing number of tools for researchers and practitioners (see for example the Ecosystems Knowledge Network Tool Assessor: https://ecosystemsknowledge.net/tool).
With this increased access to ecosystem services information, the main challenge is to incorporate the long-term holistic thinking promoted by resilience approaches to ensure that implementation of natural infrastructure can provide benefits in the present and into the future (Andersson et al., 2017). This supports the idea that the communities of practice can build on each other's strengths to support their long-term goals.

\section{CONCLUSION}

Multiple communities of research and practice contribute to urban sustainability knowledge, and these need to be recognized to bridge the gap between research and practice. Here we have analyzed the strengths of ecosystem services and resilience approaches to support natural infrastructure planning, and assessed how they played out in practice in a case study in the San Francisco Bay Area, United States. We showed that ecosystem services could provide salient information for urban planning and assess the multifunctionality, benefits, and tradeoffs of natural infrastructure. On the other hand, resilience practice helps promote a holistic understanding of the system, focusing on urban systems dynamics (e.g., management feedback loops, governance processes) that are key to sustaining long-term benefits of natural infrastructure. Our analysis demonstrates how the approaches complement each other by striking a balance between a focus on urban systems' structure and dynamics. Continued interactions between the two communities of practice will help leverage the respective strengths of each approach to inform decisions on natural infrastructure in urban planning.

\section{DATA AVAILABILITY STATEMENT}

The original contributions presented in the study are included in the article/supplementary material, further inquiries can be directed to the corresponding author.

\section{AUTHOR CONTRIBUTIONS}

All authors contributed to the design and participatory action research described in the manuscript. $\mathrm{PH}, \mathrm{AG}, \mathrm{EA}, \mathrm{JK}$, and $\mathrm{MH}$ wrote the original draft. All authors reviewed and edited the final manuscript. JS, KA, and PH collected data for ecosystem services analyses and figures. AG and GD initiated the research and acquired funding.

\section{ACKNOWLEDGMENTS}

We acknowledge the Marianne and Marcus Wallenberg Foundation, the Gordon and Betty Moore Foundation, and the LuEsther T. Mertz Charitable Trust for funding this research. We thank Shaikh Fairul Edros Ahmad Shaikh for his useful comments on the manuscript and Sara Borgström for useful discussions in the early stage of writing the manuscript. 


\section{REFERENCES}

Abson, D. J., von Wehrden, H., Baumgärtner, S., Fischer, J., Hanspach, J., Härdtle, W., et al. (2014). Ecosystem Services as a Boundary Object for Sustainability. Ecol. Econ. 103, 29-37. doi:10.1016/j.ecolecon.2014.04.012

Adapting to Rising Tides (2020). Adapting to Rising Tides Bay Area: Regional Sea Level Rise Vulnerability and Adaptation Study. Available at: http://www. adaptingtorisingtides.org/wp-content/uploads/2020/03/ARTBayArea_Main_Report_ Final_March2020_ADA.pdf (Accessed June 16, 2021).

Adapting to Rising Tides (2016). The ART Approach. Available at: http://www. adaptingtorisingtides.org/wp-content/uploads/2016/03/ART-Approach_webaligned_V1.pdf (Accessed June 16, 2021).

Albrechts, L. (2004). Strategic (Spatial) Planning Reexamined. Environ. Plann. B Plann. Des. 31 (5), 743-758. doi:10.1068/b3065

Andersson, E., Barthel, S., and Ahrné, K. (2007). Measuring Social-Ecological Dynamics behind the Generation of Ecosystem Services. Ecol. Appl. 17 (5), 1267-1278. doi:10.1890/06-1116.1

Andersson, E., Borgström, S., and McPhearson, T. (2017). "Double Insurance in Dealing with Extremes: Ecological and Social Factors for Making Nature-Based Solutions Last," in Nature-Based Solutions to Climate Change Adaptation in Urban Areas: Linkages between Science, Policy and Practice. Editors N. Kabisch, H. Korn, J. Stadler, and A. Bonn (Cham: Springer), 51-64. doi:10.1007/978-3319-56091-5_4

Andersson, E., Tengö, M., McPhearson, T., and Kremer, P. (2015). Cultural Ecosystem Services as a Gateway for Improving Urban Sustainability. Ecosystem Serv. 12, 165-168. doi:10.1016/j.ecoser.2014.08.002

Arkema, K. K., Guannel, G., Verutes, G., Wood, S. A., Guerry, A., Ruckelshaus, M., et al. (2013). Coastal Habitats Shield People and Property from Sea-Level Rise and Storms. Nat. Clim Change 3 (10), 913-918. doi:10.1038/nclimate1944

Bai, X., Surveyer, A., Elmqvist, T., Gatzweiler, F. W., Güneralp, B., Parnell, S., et al. (2016). Defining and Advancing a Systems Approach for Sustainable Cities. Curr. Opin. Environ. Sustainability 23, 69-78. doi:10.1016/j.cosust.2016.11.010

Baró, F., Palomo, I., Zulian, G., Vizcaino, P., Haase, D., and Gómez-Baggethun, E. (2016). Mapping Ecosystem Service Capacity, Flow and Demand for Landscape and Urban Planning: A Case Study in the Barcelona Metropolitan Region. Land Use Policy 57, 405-417. doi:10.1016/j.landusepol.2016.06.006

Bartesaghi Koc, C., Osmond, P., and Peters, A. (2017). Towards a Comprehensive green Infrastructure Typology: a Systematic Review of Approaches, Methods and Typologies. Urban Ecosyst. 20 (1), 15-35. doi:10.1007/s11252-016-0578-5

Beaumont, N. J., Mongruel, R., and Hooper, T. (2017). Practical Application of the Ecosystem Service Approach (ESA): Lessons Learned and Recommendations for the Future. Int. J. Biodiversity Sci. Ecosystem Serv. Manage. 13 (3), 68-78. doi:10.1080/21513732.2018.1425222

BenDor, T. K., Spurlock, D., Woodruff, S. C., and Olander, L. (2017). A Research Agenda for Ecosystem Services in American Environmental and Land Use Planning. Cities 60, 260-271. doi:10.1016/j.cities.2016.09.006

Benedict, M., and McMahon, E. (2006). Green Infrastructure: Linking Landscapes and Communities. Washington, DC: Island Press.

Bennett, E. M., Peterson, G. D., and Gordon, L. J. (2009). Understanding Relationships Among Multiple Ecosystem Services. Ecol. Lett. 12 (12), 1394-1404. doi:10.1111/j.1461-0248.2009.01387.x

Biggs, R., Schlüter, M., Biggs, D., Bohensky, E. L., BurnSilver, S., Cundill, G., et al. (2012). Toward Principles for Enhancing the Resilience of Ecosystem Services. Annu. Rev. Environ. Resour. 37 (1), 421-448. doi:10.1146/annurev-environ-051211-123836

Borgström, S. (2019). Balancing Diversity and Connectivity in Multi-Level Governance Settings for Urban Transformative Capacity. Ambio 48 (5), 463-477. doi:10.1007/s13280-018-01142-1

Braat, L. C., and de Groot, R. (2012). The Ecosystem Services Agenda:bridging the Worlds of Natural Science and Economics, Conservation and Development, and Public and Private Policy. Ecosystem Serv. 1 (1), 4-15. doi:10.1016/ j.ecoser.2012.07.011

Brand, F. S., and Jax, K. (2007). Focusing the Meaning(s) of Resilience: Resilience as a Descriptive Concept and a Boundary Object. Ecol. Soc. 12 (1), 23. doi:10.5751/ es-02029-120123

Bratman, G. N., Anderson, C. B., Berman, M. G., Cochran, B., de Vries, S., Flanders, J., et al. (2019). Nature and Mental Health: An Ecosystem Service Perspective. Sci. Adv. 5 (7), eaax0903. doi:10.1126/sciadv.aax0903
Brunet, L., Tuomisaari, J., Lavorel, S., Crouzat, E., Bierry, A., Peltola, T., et al. (2018). Actionable Knowledge for Land Use Planning: Making Ecosystem Services Operational. Land Use Policy 72, 27-34. doi:10.1016/ j.landusepol.2017.12.036

Buijs, A. E., Mattijssen, T. J., Van der Jagt, A. P., Ambrose-Oji, B., Andersson, E., Elands, B. H., et al. (2016). Active Citizenship for Urban green Infrastructure: Fostering the Diversity and Dynamics of Citizen Contributions through Mosaic Governance. Curr. Opin. Environ. Sustainability 22, 1-6. doi:10.1016/j.cosust.2017.01.002

Burkhard, B., Kandziora, M., Hou, Y., and Müller, F. (2014). Ecosystem Service Potentials, Flows and Demands-Concepts for Spatial Localisation, Indication and Quantification. Lo 34, 1-32. Research Article. doi:10.3097/LO.201434

Bush, J., and Doyon, A. (2019). Building Urban Resilience with Nature-Based Solutions: How Can Urban Planning Contribute? Cities 95, 102483. doi:10.1016/j.cities.2019.102483

Byrne, J. (2012). When green Is White: The Cultural Politics of Race, Nature and Social Exclusion in a Los Angeles Urban national park. Geoforum 43 (3), 595-611. doi:10.1016/j.geoforum.2011.10.002

Cohen-Shacham, E., Walters, G., Janzen, C., and Maginnis, S. (2016). Nature-based Solutions to Address Global Societal Challenges, Gland: IUCN. doi:10.2305/ IUCN.CH.2016.13.en

Colding, J., and Barthel, S. (2013). The Potential of 'Urban Green Commons' in the Resilience Building of Cities. Ecol. Econ. 86, 156-166. doi:10.1016/ j.ecolecon.2012.10.016

Colls, A., Ash, N., and Ikkala, N. (2009). Ecosystem-based Adaptation: a Natural Response to Climate Change. Available at: https://portals.iucn.org/library/sites/ library/files/documents/2009-049.pdf (Accessed June 16, 2021).

Cortinovis, C., and Geneletti, D. (2019). A Framework to Explore the Effects of Urban Planning Decisions on Regulating Ecosystem Services in Cities. Ecosystem Serv. 38, 100946. doi:10.1016/j.ecoser.2019.100946

Cortinovis, C., and Geneletti, D. (2018). Ecosystem Services in Urban Plans: What Is There, and what Is Still Needed for Better Decisions. Land Use Policy 70, 298-312. doi:10.1016/j.landusepol.2017.10.017

Cousins, J. J. (2021). Justice in Nature-Based Solutions: Research and Pathways. Ecol. Econ. 180, 106874. doi:10.1016/j.ecolecon.2020.106874

Crowe, P. R., Foley, K., and Collier, M. J. (2016). Operationalizing Urban Resilience through a Framework for Adaptive Co-management and Design: Five Experiments in Urban Planning Practice and Policy. Environ. Sci. Pol. 62, 112-119. doi:10.1016/j.envsci.2016.04.007

Daily, G. C. (1997). Nature's Services: Societal Dependence on Natural Ecosystems. Washington, DC: Island Press.

DEAL (2020). The Amsterdam City Doughnut. A Tool for Transformative Action. Available at: https://www.kateraworth.com/wp/wp-content/uploads/2020/04/ 20200406-AMS-portrait-EN-Single-page-web-420x210mm.pdf (Accessed June 16, 2021).

Depietri, Y., and McPhearson, T. (2017). "Integrating the Grey, Green, and Blue in Cities: Nature-Based Solutions for Climate Change Adaptation and Risk Reduction," in Nature-Based Solutions to Climate Change Adaptation in Urban Areas: Linkages between Science, Policy and Practice. Editors N. Kabisch, H. Korn, J. Stadler, and A. Bonn (Springer International Publishing), 91-109. doi:10.1007/978-3-319-56091-5_6

Díaz, S., Demissew, S., Carabias, J., Joly, C., Lonsdale, M., Ash, N., et al. (2015). The IPBES Conceptual Framework - Connecting Nature and People. Curr. Opin. Environ. Sustainability 14, 1-16. doi:10.1016/j.cosust.2014.11.002

Díaz, S., Pascual, U., Stenseke, M., Martín-López, B., Watson, R. T., Molnár, Z., et al. (2018). Assessing Nature's Contributions to People. Science 359 (6373), 270-272. doi:10.1126/science.aap8826

Elmqvist, T., Andersson, E., Frantzeskaki, N., McPhearson, T., Olsson, P., Gaffney, O., et al. (2019). Sustainability and Resilience for Transformation in the Urban century. Nat. Sustain. 2 (4), 267-273. doi:10.1038/s41893-019-0250-1

Enfors-Kautsky, E., Järnberg, L., Quinlan, A., and Ryan, P. (2018). Wayfinder: a Resilience Guide for Navigating towards Sustainabile Futures. Available at: www.wayfinder.earth (Accessed June 16, 2021).

Ernstson, H., Barthel, S., Andersson, E., and Borgström, S. T. (2010). ScaleCrossing Brokers and Network Governance of Urban Ecosystem Services: The Case of Stockholm. Ecol. Soc. 15. doi:10.5751/ES-03692-150428

Fisher, D. R., Campbell, L. K., and Svendsen, E. S. (2012). The Organisational Structure of Urban Environmental Stewardship. Environ. Polit. 21 (1), 26-48. doi:10.1080/09644016.2011.643367 
Folke, C., Biggs, R., Norström, A. V., Reyers, B., and Rockström, J. (2016). Socialecological Resilience and Biosphere-Based Sustainability Science. Ecol. Soc. 21 (3), 41. doi:10.5751/ES-08748-210341

Frantzeskaki, N. (2019). Seven Lessons for Planning Nature-Based Solutions in Cities. Environ. Sci. Pol. 93, 101-111. doi:10.1016/j.envsci.2018.12.033

Geneletti, D., Cortinovis, C., Zardo, L., and Adem Esmail, B. (2020). Planning for Ecosystem Services in Cities. Cham: Springer. doi:10.1007/978-3-030-20024-4

Geneletti, D., and Zardo, L. (2016). Ecosystem-based Adaptation in Cities: An Analysis of European Urban Climate Adaptation Plans. Land Use Policy 50, 38-47. doi:10.1016/j.landusepol.2015.09.003

Global Covenant of Mayors and C40 (2018). Summary for Urban Policy Makers What the IPCC Special Report on Global Warming of 1.5C Means for Cities. doi:10.24943/SCPM.2018

Hansen, R., Frantzeskaki, N., McPhearson, T., Rall, E., Kabisch, N., Kaczorowska, A., et al. (2015). The Uptake of the Ecosystem Services Concept in Planning Discourses of European and American Cities. Ecosystem Serv. 12, 228-246. doi:10.1016/j.ecoser.2014.11.013

Hernantes, J., Maraña, P., Gimenez, R., Sarriegi, J. M., and Labaka, L. (2019). Towards Resilient Cities: A Maturity Model for Operationalizing Resilience. Cities 84, 96-103. doi:10.1016/j.cities.2018.07.010

Hobbs, R. J., Arico, S., Aronson, J., Baron, J. S., Bridgewater, P., Cramer, V. A., et al. (2006). Novel Ecosystems: Theoretical and Management Aspects of the New Ecological World Order. Glob. Ecol. Biogeogr. 15 (1), 1-7. doi:10.1111/j.1466822X.2006.00212.x

Hochard, J. P., Hamilton, S., and Barbier, E. B. (2019). Mangroves Shelter Coastal Economic Activity from Cyclones. Proc. Natl. Acad. Sci. USA 116 (25), 12232-12237. doi:10.1073/pnas.1820067116

Johnson, M. L., Locke, D. H., Svendsen, E., Campbell, L. K., Westphal, L. M., Romolini, M., et al. (2019). Context Matters: Influence of Organizational, Environmental, and Social Factors on Civic Environmental Stewardship Group Intensity. Ecol. Soc. 24 (4), 1. doi:10.5751/ES-10924-240401

Kabisch, N., Frantzeskaki, N., Pauleit, S., Naumann, S., Davis, M., Artmann, M., et al. (2016). Nature-based Solutions to Climate Change Mitigation and Adaptation in Urban Areas: Perspectives on Indicators, Knowledge Gaps, Barriers, and Opportunities for Action. Ecol. Soc. 21 (2), 39. doi:10.5751/ES-08373-210239

Kaczorowska, A., Kain, J.-H., Kronenberg, J., and Haase, D. (2016). Ecosystem Services in Urban Land Use Planning: Integration Challenges in Complex Urban Settings-Case of Stockholm. Ecosystem Serv. 22, 204-212. doi:10.1016/ j.ecoser.2015.04.006

Keating, A., and Hanger-Kopp, S. (2020). Practitioner Perspectives of Disaster Resilience in International Development. Int. J. Dis. Risk Red. 42. doi:10.1016/ j.ijdrr.2019.101355

Keeler, B. L., Hamel, P., McPhearson, T., Hamann, M. H., Donahue, M. L., Meza Prado, K. A., et al. (2019). Social-ecological and Technological Factors Moderate the Value of Urban Nature. Nat. Sustain. 2 (1), 29-38. doi:10.1038/s41893-018-0202-1

Kremer, P., Hamstead, Z., Haase, D., McPhearson, T., Frantzeskaki, N., Andersson, E., et al. (2016). Key Insights for the Future of Urban Ecosystem Services Research. Ecol. Soc. 21 (2), 29. doi:10.5751/ES-08445-210229

Lafortezza, R., Chen, J., van den Bosch, C. K., and Randrup, T. B. (2018). Naturebased Solutions for Resilient Landscapes and Cities. Environ. Res. 165, 431-441. doi:10.1016/j.envres.2017.11.038

Langridge, S. M., Hartge, E. H., Clark, R., Arkema, K., Verutes, G. M., Prahler, E. E., et al. (2014). Key Lessons for Incorporating Natural Infrastructure into Regional Climate Adaptation Planning. Ocean Coastal Manage. 95, 189-197. doi:10.1016/j.ocecoaman.2014.03.019

Lavine, E. (2013). Adapting Governance for Rising Tides. doi:10.1057/ 9781137307224

Leigh Star, S. (2010). This Is Not a Boundary Object: Reflections on the Origin of a Concept. Sci. Technol. Hum. Values 35 (5), 601-617. doi:10.1177/ 0162243910377624

Luederitz, C., Brink, E., Gralla, F., Hermelingmeier, V., Meyer, M., Niven, L., et al. (2015). A Review of Urban Ecosystem Services: Six Key Challenges for Future Research. Ecosystem Serv. 14, 98-112. doi:10.1016/j.ecoser.2015.05.001

Masterson, V. A., Vetter, S., Chaigneau, T., Daw, T. M., Selomane, O., Hamann, M., et al. (2019). Revisiting the Relationships between Human Well-Being and Ecosystems in Dynamic Social-Ecological Systems: Implications for Stewardship and Development. Glob. Sustain. 2, e8. doi:10.1017/sus.2019.5
McPhearson, T., Andersson, E., Elmqvist, T., and Frantzeskaki, N. (2015). Resilience of and through Urban Ecosystem Services. Ecosystem Serv. 12, 152-156. doi:10.1016/j.ecoser.2014.07.012

McPhearson, T., Haase, D., Kabisch, N., and Gren, Å. (2016). Advancing Understanding of the Complex Nature of Urban Systems. Ecol. Indicators 70, 566-573. doi:10.1016/j.ecolind.2016.03.054

Meerow, S., Newell, J. P., and Stults, M. (2016). Defining Urban Resilience: A Review. Landscape Urban Plann. 147, 38-49. doi:10.1016/ j.landurbplan.2015.11.011

Meerow, S., and Newell, J. P. (2019). Urban Resilience for Whom, What, When, Where, and Why? Urban Geogr. 40 (3), 309-329. doi:10.1080/ 02723638.2016 .1206395

Munang, R., Thiaw, I., Alverson, K., Liu, J., and Han, Z. (2013). The Role of Ecosystem Services in Climate Change Adaptation and Disaster Risk Reduction. Curr. Opin. Environ. Sustainability 5 (1), 47-52. doi:10.1016/ j.cosust.2013.02.002

Nutters, H. (2012). Addressing Social Vulnerability and Equity in Climate Change Adaptation Planning. Available at: http://www.adaptingtorisingtides.org/wpcontent/uploads/2015/04/ART_Equity_WhitePaper.pdf (Accessed June 16, 2021).

Ochoa, V., and Urbina-Cardona, N. (2017). Tools for Spatially Modeling Ecosystem Services: Publication Trends, Conceptual Reflections and Future Challenges. Ecosystem Serv. 26, 155-169. doi:10.1016/j.ecoser.2017.06.011

Ozment, S., Ellison, G., and Jongman, B. (2019). Nature-Based Solutions for Disaster Risk Management: Booklet. Available at: http://documents1. worldbank.org/curated/en/253401551126252092/pdf/134847-NBS-for-DRMbooklet.pdf (Accessed June 16, 2021).

Palomo, I., Felipe-Lucia, M. R., Bennett, E. M., Martín-López, B., and Pascual, U. (2016). "Disentangling the Pathways and Effects of Ecosystem Service CoProduction," in Ecosystem Services: From Biodiversity to Society, Part 2. Editors G. Woodward and D. A. Bohan (Cambridge, Massachusetts: Academic Press), 54, 245-283. doi:10.1016/bs.aecr.2015.09.003

Pascual, U., Balvanera, P., Díaz, S., Pataki, G., Roth, E., Stenseke, M., et al. (2017). Valuing Nature's Contributions to People: the IPBES Approach. Curr. Opin. Environ. Sustainability 26-27, 7-16. doi:10.1016/j.cosust.2016.12.006

Pauleit, S., Hansen, R., Rall, E. L., Zölch, T., Andersson, E., Luz, A. C., et al. (2017). "Urban Landscapes and green Infrastructure," in Oxford Research Encyclopedia of Environmental Science. doi:10.1093/acrefore/9780199389414.013.23

Phillips, C. A., Caldas, A., Cleetus, R., Dahl, K. A., Declet-Barreto, J., Licker, R., et al. (2020). Compound Climate Risks in the COVID-19 Pandemic. Nat. Clim. Chang. 10, 586-588. doi:10.1038/s41558-020-0804-2

Quinlan, A. E., Berbés-Blázquez, M., Haider, L. J., and Peterson, G. D. (2015). Measuring and Assessing Resilience: Broadening Understanding through Multiple Disciplinary Perspectives. J. Appl. Ecol. 53 (3), 677-687. doi:10.1111/1365-2664.12550

Revi, A., Satterthwaite, D. E., Aragón-Durand, F., Corfee-Morlot, J., Kiunsi, R. B. R., Pelling, M., et al. (2014). "Urban Areas," in Climate Change 2014: Impacts, Adaptation, and Vulnerability. Part A: Global and Sectoral Aspects. Contribution of Working Group II to the Fifth Assessment Report of the Intergovernmental Panel on Climate Change. Editors C. B. Field, V. R. Barros, D. J. Dokken, K. J. Mach, M. D. Mastrandrea, T. E. Bilir, et al. (Cambridge, United Kingdom and New York, United States: University Press), 535-612.

Reyers, B., Biggs, R., Cumming, G. S., Elmqvist, T., Hejnowicz, A. P., and Polasky, S. (2013). Getting the Measure of Ecosystem Services: a Social-Ecological Approach. Front. Ecol. Environ. 11 (5), 268-273. doi:10.1890/120144

Reyers, B., Folke, C., Moore, M.-L., Biggs, R., and Galaz, V. (2018). SocialEcological Systems Insights for Navigating the Dynamics of the Anthropocene. Annu. Rev. Environ. Resour. 43 (1), 267-289. doi:10.1146/ annurev-environ-110615-085349

Rockefeller Foundation; ARUP (2014). City Resilience Index. Available at: https:// www.arup.com/perspectives/publications/research/section/city-resilienceindex (Accessed June 16, 2021).

Romero-Lankao, P., Gnatz, D., Wilhelmi, O., and Hayden, M. (2016). Urban Sustainability and Resilience: From Theory to Practice. Sustainability 8 (12), 1224. doi: $10.3390 /$ su8121224

Rosenthal, A., Verutes, G., McKenzie, E., Arkema, K. K., Bhagabati, N., Bremer, L. L., et al. (2015). Process Matters: a Framework for Conducting DecisionRelevant Assessments of Ecosystem Services. Int. J. Biodiversity Sci. Ecosystem Serv. Manage. 11 (3), 190-204. doi:10.1080/21513732.2014.966149 
Ruckelshaus, M., McKenzie, E., Tallis, H., Guerry, A., Daily, G., Kareiva, P., et al. (2015). Notes from the Field: Lessons Learned from Using Ecosystem Service Approaches to Inform Real-World Decisions. Ecol. Econ. 115, 11-21. doi:10.1016/J.ECOLECON.2013.07.009

Saarikoski, H., Primmer, E., Saarela, S.-R., Antunes, P., Aszalós, R., Baró, F., et al. (2018). Institutional Challenges in Putting Ecosystem Service Knowledge in Practice. Ecosystem Serv. 29, 579-598. doi:10.1016/j.ecoser.2017.07.019

Samuelsson, K., Colding, J., and Barthel, S. (2019). Urban Resilience at Eye Level: Spatial Analysis of Empirically Defined Experiential Landscapes. Landscape Urban Plann. 187, 70-80. doi:10.1016/j.landurbplan.2019.03.015

Schleyer, C., Lux, A., Mehring, M., and Görg, C. (2017). Ecosystem Services as a Boundary Concept: Arguments from Social Ecology. Sustainability 9 (7), 1107. doi:10.3390/su9071107

Sellberg, M. M., Ryan, P., Borgström, S. T., Norström, A. V., and Peterson, G. D. (2018). From Resilience Thinking to Resilience Planning: Lessons from Practice. J. Environ. Manage. 217, 906-918. doi:10.1016/j.jenvman.2018.04.012

Sellberg, M. M., Wilkinson, C., and Peterson, G. D. (2015). Resilience Assessment: a Useful Approach to Navigate Urban Sustainability Challenges. Ecol. Soc. 20 (1), 43. doi:10.5751/ES-07258-200143

Shi, L., Chu, E., Anguelovski, I., Aylett, A., Debats, J., Goh, K., et al. (2016). Roadmap towards justice in Urban Climate Adaptation Research. Nat. Clim Change 6 (2), 131-137. doi:10.1038/nclimate2841

Silva, J. M. C. d., and Wheeler, E. (2017). Ecosystems as Infrastructure. Perspect. Ecol. Conservation 15 (1), 32-35. doi:10.1016/j.pecon.2016.11.005

Spaans, M., and Waterhout, B. (2017). Building up Resilience in Cities Worldwide Rotterdam as Participant in the 100 Resilient Cities Programme. Cities 61, 109-116. doi:10.1016/j.cities.2016.05.011

Steen Møller, M., and Stahl Olafsson, A. (2018). The Use of E-Tools to Engage Citizens in Urban Green Infrastructure Governance: Where Do We Stand and Where Are We Going? Sustainability 10 (10), 3513. doi:10.3390/su10103513

Steger, C., Hirsch, S., Evers, C., Branoff, B., Petrova, M., Nielsen-Pincus, M., et al. (2018). Ecosystem Services as Boundary Objects for Transdisciplinary Collaboration. Ecol. Econ. 143, 153-160. doi:10.1016/j.ecolecon.2017.07.016

Tallis, H., Mooney, H., Andelman, S., Balvanera, P., Cramer, W., Karp, D., et al. (2012). A Global System for Monitoring Ecosystem Service Change. BioScience 62 (11), 977-986. doi:10.1525/bio.2012.62.11.7

Thompson, K., Sherren, K., and Duinker, P. N. (2019). The Use of Ecosystem Services Concepts in Canadian Municipal Plans. Ecosystem Serv. 38, 100950. doi:10.1016/j.ecoser.2019.100950

Thorén, H. (2014). Resilience as a Unifying Concept. Int. Stud. Philos. Sci. 28 (3), 303-324. doi:10.1080/02698595.2014.953343

Turkelboom, F., Leone, M., Jacobs, S., Kelemen, E., García-Llorente, M., Baró, F., et al. (2018). When We Cannot Have it All: Ecosystem Services Trade-Offs in the Context of Spatial Planning. Ecosystem Serv. 29, 566-578. doi:10.1016/ j.ecoser.2017.10.011

United Nations (2016). HABITAT III. New Urban Agenda. Available at: http:// habitat3.org/wp-content/uploads/New-Urban-Agenda-GA-Adopted-68th-PlenaryN1646655-E.pdf (Accessed June 16, 2021).
United Nations (2015). Transforming Our World: The 2030 Agenda for Sustainable Development. Available at: sustainabledevelopment.un.org (Accessed June 16, 2021).

van de Ven, F. H. M., Snep, R. P. H., Koole, S., Brolsma, R., van der Brugge, R., Spijker, J., et al. (2016). Adaptation Planning Support Toolbox: Measurable Performance Information Based Tools for Co-creation of Resilient, Ecosystem-Based Urban Plans with Urban Designers, Decision-Makers and Stakeholders. Environ. Sci. Pol. 66, 427-436. doi:10.1016/j.envsci.2016.06.010

Wagenaar, H., and Wilkinson, C. (2015). Enacting Resilience: A Performative Account of Governing for Urban Resilience. Urban Stud. 52 (7), 1265-1284. doi:10.1177/0042098013505655

Walker, B., and Salt, D. (2012). Resilience Practice: Building Capacity to Absorb Disturbance and Maintain Function. Washington, DC: Island Press. doi:10.5822/978-1-61091-231-0

Wamsler, C., Niven, L., Beery, T. H., Bramryd, T., Ekelund, N., Jönsson, K. I., et al. (2016). Operationalizing Ecosystem-Based Adaptation: Harnessing Ecosystem Services to Buffer Communities against Climate Change. Ecol. Soc. 21 (1), 31. doi:10.5751/ES-08266-210131

Wang, D., Brown, G., and Liu, Y. (2015). The Physical and Non-physical Factors that Influence Perceived Access to Urban parks. Landscape Urban Plann. 133, 53-66. doi:10.1016/j.landurbplan.2014.09.007

Wardekker, A., Wilk, B., Brown, V., Uittenbroek, C., Mees, H., Driessen, P., et al. (2020). A Diagnostic Tool for Supporting Policymaking on Urban Resilience. Cities 101, 102691. doi:10.1016/..cities.2020.102691

Wilkinson, C. (2011). Social-ecological Resilience: Insights and Issues for Planning Theory. Plann. Theor. 11 (2), 148-169. doi:10.1177/1473095211426274

World Bank Group (2021). Resilience Rating System: A Methodology for Building and Tracking Resilience to Climate Change. Available at: https:// openknowledge.worldbank.org/handle/10986/35039 (Accessed June 16, 2021).

World Bank (2017). Implementing Nature-Based Flood protection: Principles and Implementation Guidance. Available at: https://openknowledge.worldbank. org/ (Accessed June 16, 2021).

WWAP/UN-Water (2018). The United Nations World Water Development Report 2018: Nature-Based Solutions for Water. Available at: https://www. unwater.org/world-water-development-report-2018-nature-based-solutions-forwater/ (Accessed June 16, 2021).

Conflict of Interest: The authors declare that the research was conducted in the absence of any commercial or financial relationships that could be construed as a potential conflict of interest.

Copyright (c) 2021 Hamel, Hamann, Kuiper, Andersson, Arkema, Silver, Daily and Guerry. This is an open-access article distributed under the terms of the Creative Commons Attribution License (CC BY). The use, distribution or reproduction in other forums is permitted, provided the original author(s) and the copyright owner(s) are credited and that the original publication in this journal is cited, in accordance with accepted academic practice. No use, distribution or reproduction is permitted which does not comply with these terms. 